\title{
An Examination of Intragroup Process in Service-Learning Teams
}

\author{
Randy Fall ${ }^{1}$, Mark Dickerson ${ }^{2}$, Roxanne Helm-Stevens ${ }^{2}$ \\ ${ }^{1}$ School of Education, Azusa Pacific University, California, United States of America \\ ${ }^{2}$ School of Business and Management, Azusa Pacific University, California, United States of America \\ Correspondence: Roxanne Helm-Stevens, School of Business and Management, Azusa Pacific University, School of \\ Business and Management, 901 East Alosta Avenue, Azusa, CA 91702, USA.
}

\author{
Received: January 19, 2021 \\ doi:10.11114/ijce.v4i1.5202 \\ Accepted: March 27, $2021 \quad$ Online Published: March 28, 2021 \\ URL: https://doi.org/10.11114/ijce.v4i1.5202
}

\begin{abstract}
Small group work performed in the context of university service-learning projects has been seen as a vehicle well-suited to teaching students about group dynamics and how to work on real world problems as members of a team. Little research, however, has focused on the intragroup processes involved in service-learning. The present study was conducted in the context of a service-learning project in which twenty groups of four to five university business school students taught continuation high school students a series of lessons regarding life skills such as goal setting and career readiness. The lesson planning sessions of the university students were video recorded and the videos were then analyzed for patterns of utterances by group participants (questions; instructions; suggestions; etc.) that occurred during the sessions. An iterative process of coding and recoding was employed to capture each behavior for further study. The results suggest that the groups engaged in a surprising level of meaningful collaboration, with leadership shared among group members, and little evidence of individual dominance of groups, or conflict between students.
\end{abstract}

Keywords: service-learning, teams, group work, leadership

\section{Introduction}

A number of scholars have noted that a possible benefit of service learning projects is that students may develop an understanding of group dynamics and teamwork. In their seminal work on service-learning, Elyer and Giles (1999) reported that 40 percent of students surveyed indicated that learning to work with others was a key learning in their service experience. Similarly, Yelsma (1999) claimed that "when faced with real challenges that affect group members and people in the community, students seem more compelled to learn methods of working together as a team" (p. 87). Yelsma goes on to outline the value of service-learning as a pedagogy best-practice in accomplishing team and group educational objectives, including the areas of group roles, team dynamics, and decision-making. Expanding on the notion of using teams in service-learning, Falk adds, "Service learning courses can benefit from a team approach because service learning is intended to address real-world problems and real-world problems demand the attention of teams" (2012, p. 4). Vaughn (2010) was struck by the value of a service-learning project in shifting students' opinions about teamwork after observing her students within the context of a group communication class. Noting the power of the class service-learning project in increasing students' appreciation for teamwork, including meeting management and goal-attainment, Vaughn also observed that her students were able to use theory and concepts to analyze their experiences.

Wurr and Hamilton (2012) further suggest that service-learning also provides a crucible for student leadership development, arguing that its greatest potential contribution to student leadership development occurs during Stages 3 and 4 of Komives et al.'s (2005) Leadership Identity Development Theory. This is the period when individuals are trying on new roles and responsibilities and becoming aware that leadership is a group process (2005, p. 227). While the studies are not definitive, a number of other scholars support the proposition that service-learning projects provide an opportunity to develop student leadership behaviors such as interpersonal communications, conflict resolution, problem solving, delegation, planning and encouragement of others (Dickerson, Helm-Stevens \& Fall, 2017; Foli, et al., 2014; Lester, 2015; and Zlotkowski, 2006).

Despite the number of references to group dynamics in the service-learning literature, further research is needed. Researchers have noted of the lack of investigation into interaction processes in cooperative learning groups (Webb, 
1982) and the overall lack of attention to student relationships and teamwork in service-learning (Helm-Stevens \& Griego, 2009). Acknowledging the lack of literature, Falk summarized "while there is a sizable literature on teamwork and a growing literature on service learning, there is limited literature on teamwork in the context of service learning" (2012, p. 5). Questions deserving further examination include: Who leads the group when there is no designated leader? How do team members relate to each other? Does the team operate through a creative, collaborative process, a competition among dissenting members or the disconnected efforts of multiple team members?

\section{Literature Review}

\section{Team Leadership}

In many service-learning projects, students are expected to work in small groups to plan and implement the assigned service-learning intervention without the assignment of a team leader or detailed directions regarding the process they should follow. Small group research suggests that the group's decision to either share leadership responsibilities or select a strong internal leader is influenced by a number of factors.

Early studies of small work teams suggested that one or two informal leaders tended to emerge in leaderless work groups (Bales, 1958; Slater, 1955). However, more recent research has studied the phenomenon of shared leadership and similar constructs such as distributed leadership, collective leadership, participative leadership and peer leadership and examined the conditions under which leader functions will be shared or an internal leader will emerge. Two of the leading scholars on shared leadership define it as "a dynamic, interactive influence process among individuals for which the objective is to lead one another to the achievement of group or organizational goals or both" (Pearce \& Conger, 2003a, p. 1.).

Seers, et al. (2003) examined the question of shared leadership versus vertical leadership in work teams and suggested a number of factors that could influence the choice between the two. Inhibitors of shared leadership include individual differences in status seeking, evidence of strong status differentials, members' implicit prototypes of a leader, individual resistance to the concept, and demographic diversity that creates perceived status differences among members (see also, Dickson, Resick \& Hanges, 2006). Facilitators of shared leadership include strong norms for social exchange, interpersonal attraction, positive perceptions of others' abilities to contribute to the task, larger group size and complex tasks that require role differentiation (see also, D'Innocenzo, et al., 2016).

\section{Team Member Relationships}

Aside from questions of team leadership, how do team members interact with one another? At one extreme end of the continuum, students can have very limited interaction, with each student working independently on the group assignment. In their volume entitled An Overview of Cooperative Learning, Johnson and Johnson (1994) noted a significant difference between assigning students to group work and structuring group assignments that require students to work cooperatively. They observed that "putting students into groups does not necessarily gain a cooperative relationship; it has to be structured and managed by the teacher or professor" (Johnson \& Johnson, 1994, p. 508). When groups are not structured to promote interaction and cooperation, students pressed by multiple demands on their time commonly utilize a division of labor method to complete group assignments. Simply put, "a group of students sitting at the same table doing their work, but free to talk with each other as they work is not structured to be a cooperative group, as there is no positive interdependence" (Johnson \& Johnson, 1994, p. 508). While examining interactive processes and student outcomes in small groups, Battistich, Solomon and Delucchi (1993) found that competent teachers created "better quality" group experiences, in part, by effectively "setting up groups and encouraging cooperative activities" (p. 29).

In a review of research regarding small groups learning educational material at the elementary and secondary school level concluded that student ability and reward structure were the variables most consistently related with student interaction (Webb, 1982). A subsequent study by Webb and colleagues (Fall, Webb \& Chudowsky, 2000) went further, suggesting that the quality of student interactions depended partly on the composition of the group: ability of the participating students, their demographic characteristics, personalities of the participants (were students outgoing, friendly, domineering, etc.?), the students' motivation to perform the assigned task, their relative peer-group and/or academic status and their skill in collaborating effectively with others.

Outside of the educational context, factors shown to increase collaboration in small groups include goal interdependence (Tjosvold, 1988), team cohesion, open and clear communication, involvement in consensus-based decision making, joint goal setting, equality of status, and mutual respect (Hackman, 1987; Nijhuis, et al., 2007). In turn, team cohesion includes both task cohesion (commitment of all team members to a common goal) and social cohesion (positive feelings among team members). Carless and De Paola (2000) found that task and social cohesion are positively related to team spirit, social support among team members, communication, cooperation, workload sharing, 
participation in team decision-making, and alignment between team goals and individual goals.

Conversely, collaboration can be inhibited by indifference to responsibility by team members, failure to communicate, or ignoring team member input (Tjosvold, 1995). One example of reduced collaboration would be social loafing with one or two students riding on the coattails of their peers. Researchers have found higher levels of social loafing when the task is unmotivating (George, 1992) or in larger groups (Liden, et al., 2004). Ironically, the interdependence of the task can lead to an increase in social loafing in a team because members are not held accountable individually.

Accordingly, social loafing may be moderated by group cohesiveness (Karau \& Williams, 1997; Karau \& Williams, 1993), evaluation of individual inputs (e.g., individual efforts evaluated for a grade, Harkins \& Jackson, 1985; see also, Harkins \& Szymanski, 1989; Szymanski \& Harkins, 1987; Williams, Harkins, \& Latane, 1981), recognizing the uniqueness of individual contributions (Harkins \& Petty, 1982), or enhancing personal involvement with the task (Brickner, Harkins, \& Ostrom, 1986). Another factor mitigating against social loafing may be team member motivation to participate in meaningful work (Van der Vegt, Emans, et al., 1998).

Of course, collaboration can be negatively impacted or destroyed by dysfunctional conflict within the group. Common causes of dysfunctional conflict include differences among team members in styles and values, team member failure to perform their share of the work, miscommunication, misperception and misinformation and individual goals that conflict with team goals (Franz, 2012, pp. 204-210; Jehn, 1995; Jehn, et al., 1999; Tjsovold, 1986). Competitive behaviors can also increase levels of conflict due to a reduction in trust levels (Cook, Hardin, \& Levi, 2005).

One variable that has been found to impact group dynamics is the motivation of individual team members. In describing a service-learning project in which college students participated in conflict resolution activities with middle school students, Raskoff (1997) noted that the motivation of college students participating in service-earning programs can significantly impact their reactions to the experience and their group interactions. She found that "[a] schism appeared in the group of college students, separating those who were very serious about their participation in the project from those who were more casual in their motivation for participating" (p. 112).

In other research, Petersen and Gadija (2017) found group conflict in a multi-year service-learning program involving teacher education students in South Africa. The multiracial and multilingual makeup of the group posed language barriers, gender expectations, and conflicting cultural expectations. Differences in work ethics and negotiations over group norms also led to conflicts that required resolution.

Similarly, a study of interactions among six student teachers planning instruction together during a 16-week student teaching practicum revealed conflicts stemming from different working styles and contrasting visions of teaching, with complaints that teammates were not carrying completing their assignments on a timely basis or failing to share changes they make in lesson plans (Gallo-Fox \& Scantlebury, 2015). This led to a deterioration in working relationships. The facilitator for the group remarked that "Some of them don't really get along with the others, can't really stand each other ...." (p. 334).

Finally, complex decision-making processes have been found to generate stress and resistance in service-learning groups. Stenhouse and Jarrett (2012) implemented a Problem Solution Project (PSP) with multiple cohorts of preservice teachers and their students over a five-year period. For each cohort, the PSP required participants to engage in a consensus-based process in which they would identify and attempt to solve a problem selected by the group. While some cohorts navigated the process with little conflict, others struggled with strong personalities, member resistance and disparate visions of the need, value and reach of the project that they were to adopt. One participant noted that "having a lot of adults agree on one topic was difficult. I also think getting everyone involved was difficult too" (p. 62). Another cohort member observed that "The biggest problem I saw/felt was the overall apathy of the group ... Because there was no 'leader' it was more difficult" (p. 62).

In sum, prior research suggests that the processes of group leadership and team interaction within small service-learning teams with no designated leader depend upon the personalities of team members as well as the situational and procedural contexts of the service-learning group assignments. Clearly, further study is required to shed light on team dynamics by parsing out the relevant variables.

\section{Research Design}

This study was designed based on a method developed by Fall, Webb and Chudowsky (2001) for the study of verbal interactions in groups. In this approach, verbalizations are coded into categories based on the function of the verbalization. Counts of codes are then used to compare forms of interactions across and within groups. Our investigation focused on two variables in forms of interaction: cooperation vs. competition, and individual dominance in leadership vs. collaborative leadership, we sought to discover whether undergraduate students in this service-learning context would engage in a mix of competitive and collaborative interactions, as had been found in previous studies with 
other populations. We also expected that some groups would be characterized by cooperation and collaboration, while others would be competitive. Regarding leadership, we similarly expected that some individuals would dominate a group as a leader, while other groups would engage in more distributed and collaborative leadership.

\section{Empirical Context and Research Methodology}

Participants included 78 subjects, 41 males and 37 females. The participants were videorecorded in a total of 20 group meetings with usable data, typically with 5 students per group. Data on ages were not collected, though the age-range of undergraduate students in the major was from 18 to 23. Ethnicities were also not collected for this sample, but the ethnicities for the School of Business overall were: White $37.12 \%$, Hispanic $28.44 \%$, Asian $8.8 \%$, Black or African-American 6.12\%, Native Hawaiian 1.4\%, Two or more races $8.8 \%$, Nonresident Alien $8.9 \%$, and Decline to state $1.5 \%$. Students met in collaborative groups to plan their activities with the elementary students. Most groups had five members, though, due to absences, some coded instances had as few as three members on particular days.

Participants of the research were students in the Bachelor of Business Management program enrolled in the upper-division course, BUSI448 Organizational and Administrative Behavior. This course was chosen due to its large student enrollment and its involvement in community service-learning. In a typical semester, more than 150 students are enrolled and serve at local continuation education high schools in seven school districts throughout eastern Los Angeles County. The service-learning project, an integrative, six-week assignment, requires upper-division business majors to plan and deliver business education and life skills curriculum to at-risk secondary students. In groups of five to seven, university students were assigned a classroom where they taught one-hour lesson plans once a week for six consecutive weeks. The amount of total time at the high school was seven weeks, including one-week of orientation with the principal or school counselor and six weeks in the classroom.

Student groups were formed with the specific intent of having students experience group formation and group dynamics. In class, students completed short personality assessments and work-style preference questionnaires. Each group was carefully formed to ensure diversity of personalities (A versus B personality, locus of control, etc.), study characteristics, experiences, dominant group role (task versus socio-emotional), skill sets and overall comfort levels in teaching and working with youth. Prior to their group work, students are provided with didactic material on group dynamics through course lectures and textbook readings.

Roles and job responsibilities within the group rotated over the six weeks of classroom teaching, allowing all members to experience different team roles, understand their personal strengths and weaknesses, and experience the team leader position. In addition to rotating the leadership position, groups were also required to rotate the roles of secretary (assigned with producing and turning in the weekly group report), manager (assigned with coordinating logistics and supplies for the week), and team member. Although students were instructed to rotate roles, in actual practice most groups adopted a shared leadership model.

Once groups were formed, each group was tasked with completing a group contract requiring the signature of each group member. As part of the instructions, students were advised to create a robust group contract as each group had the opportunity to expel group members out of the group. Students were forewarned that the group contract would be used in dispute resolution if/when a group decided to expel a group member. Two stories of previous team member expulsions were shared--one group accused a member of being a "couch potato," and another group accused a member of being an autocratic leader/dictator. Note: Once a student is no longer part of the group, they are unable to participate in the service-learning project (heavily weighted in the syllabus) and it becomes difficult for that student to successfully pass the class.

\section{Lesson Plans}

The curriculum utilized for this service-learning project was Options: Business Education and Life Skills for Urban Youth, a program designed to provide both academic and life skills support to under-served, at-risk youth. Developed in 2009, this modularized curriculum of discussions and exercises is based on two pillars: education--teaching high school students business education and life skills--and an open environment--creating opportunities for discussion and dialogue. Lessons included study skills, goal setting, leadership, teamwork, and planning for future employment.

Because the Options: Business Education and Life Skills curriculum was developed with education and open dialogue as core dual objectives, it is highly interactive (embedded with educational activities, exercises, and discussions). The lesson plans are designed to provide opportunities for discussion and sharing, thereby creating openings for relationships between the university students and the high school students. Over the years, many university students have returned to the high schools, starting discussion groups, volunteering, and serving as mentors.

Data Collection

Student team members met in groups in rooms designed to facilitate the collection of video data and included both 
video cameras and microphones for audio recording. At the times specified for group meetings, student workers were present outside of the meeting rooms to monitor video and audio quality. Once each group meeting was completed, the video and audio files were uploaded to a secure storage location.

Coding

Coding of the group interactions posed a novel challenge. While coding of group interactions are common in semantics and linguistics, those coding approaches have been developed for research questions quite different from ours. We followed an approach from Webb, Troper and Fall (1995), which was originally used to capture helping behaviors in recordings of elementary students' group work. Our approach entailed an iterative process of coding to capture particular content, revising the coding system, and recoding. We focused on interactions that would address the research questions: whether these students were truly working collaboratively, or if they were primarily dividing up tasks and working independently and whether they shared leadership or selected a group member to lead. We also wanted to identify behaviors that had been found in studies of interactions of elementary and high-school students, including question-asking, conflict, dominance, and ignoring. Student workers who performed most of the coding contributed a number of modifications to the coding system. After several iterations, the final coding system included 14 codes, listed in Table X.

Table X. Verbal interaction codes

\begin{tabular}{cl}
\hline Code & Description \\
\hline 1 & Initiation/ Starting or restarting \\
2 & Agreement \\
3 & Affirmation/Positive Comment (not just agreement) \\
4 & Framing/ reframing \\
5 & Elaboration/ Builds upon an idea, conversation/Adding information \\
6 & Limitation/correction \\
7 & Challenge to an idea/disagreement \\
8 & New idea, novel, new direction, new contribution \\
9 & Summarizing \\
10 & Question for information \\
11 & Social (non-content, jokes) \\
12 & Other course-related (university course) \\
13 & answers question \\
14 & Suggestions \\
\hline
\end{tabular}

\section{Results}

The coding produced a total of 6858 codes. Percentages of codes are summarized in Table Z, below. Elaboration and agreement were the most common coded interactions, representing 17 percent and 16 percent of all coded interactions, respectively. There were very low levels, less than $2 \%$ each, of summarizing, challenge to an idea/disagreement, initiation, and suggestions.

\begin{tabular}{clr}
\hline Code & Description & Percent \\
\hline 1 & Initiation/ Starting or restarting & 1 \\
2 & Agreement & 16 \\
3 & Affirmation/Positive Comment (not just agreement) & 10 \\
4 & Framing/ reframing & 11 \\
5 & Elaboration / Builds upon an idea, conversation/Adding information & 17 \\
6 & Limitation/correction & 3 \\
7 & Challenge to an idea/disagreement & 1 \\
8 & New idea, novel, new direction, new contribution & 7 \\
9 & Summarizing & 2 \\
10 & Question for information & 10 \\
11 & Social (non-content, jokes) & 11 \\
12 & Other course-related (university course) & 3 \\
13 & answers question & 6 \\
14 & Suggestions & 2 \\
\hline
\end{tabular}


Table Y. Percentages of total interactions by code

\begin{tabular}{clr}
\hline Code & Description & Percent \\
\hline 5 & Elaboration / Builds upon an idea, conversation/Adding information & 17 \\
2 & Agreement & 16 \\
11 & Social (non-content, jokes) & 11 \\
4 & Framing/reframing & 11 \\
10 & Question for information & 10 \\
3 & Affirmation/Positive Comment (not just agreement) & 10 \\
8 & New idea, novel, new direction, new contribution & 7 \\
13 & answers question & 6 \\
12 & Other course-related (university course) & 3 \\
6 & Limitation/correction & 3 \\
14 & Suggestions & 2 \\
9 & Summarizing & 2 \\
7 & Challenge to an idea/disagreement & 1 \\
1 & Initiation/ Starting or restarting & 1
\end{tabular}

The following example shows a typical form of collaborative interaction, dominated by elaboration (code 5) and agreement (code 2). It is worthwhile to note how the successive elaborations by different team members are consistently endorsed by the other team members. It is also remarkable how consistent the forms of interaction are, with a pattern of elaboration and agreement.

Student 1: Do we want to split into groups or keep the whole?

Student 2: We can just wing that depending on who comes (5)

Student 3: Yeah, since there is like 3 of them (5)

Student 1: Yeah (2)

Student 3: We can just sit as a circle (5)

Student 4: Yeah (2)

Student 2: We can have discussions, then, if they are all there, then we can split up again (5)

Student 4: Yeah, we can do the games in the morning and then hanging out later after (5)

Student 3: We did it that way one other time (4)

Student 2: Yeah (2)

Student 1: I think we can talk about, just, like we can talk about positivity and optimistic and seeing the best and that's how you can change things, so closing with that will be good. (5)

Another set of interactions from a different group illustrates the same forms of interaction, with engaged elaboration punctuated with agreements.

Student X: We told them to share and look up what they want as a career so then we can help them out look up how much

Student Y: Something that interests them, basically

Student Z: Yeah, and we will look it up how much the average job makes and...

Student X: okay

Student Y: yeah, and we will discuss about taxes and bills

Student X: yeah

Student Y: Average of salary of a job they pick and break it down, budgeting...

Student X: Also, as high schoolers we didn't really have to budget much, all allowance we had goes to candy and such. And for them too, they talked about taking girls on dates, spending it on food... 
Student Z: For your group, too, even though you have younger ones they also will need to learn about budgeting in more fun and interactive way.

The pervasiveness of agreements in the groups led us to consider how disagreements were handled when they arose. The following example illustrates a very common approach, using a question as a form to express disagreement:

Student 4: Are we sure we want to do business?

Student 5: Hmm

Student 6: I am afraid it is only going to reach one or two people in that class.

The question, "Are we sure we want to do business?" is remarkable in two aspects. First, while the content of the utterance is disagreement with the group's direction, the choice to present the disagreement as a question induces collaboration rather than conflict. Second, the question is framed as a group consideration, "Are we sure we...". That is, the form of the question affirms the collaborative activity of the group, and returns the deliberation to the group rather than expressing direct disagreement of individual with another.

In comparison to previous studies of younger students, these undergraduates demonstrate a remarkably subtle ability to use forms of verbal interaction to simultaneously solve a problem and maintain a positive social environment.

Results for specific groups of students were remarkably consistent. Elaboration and agreement were the two most frequent codes in 18 out of 20 groups. While the relative numbers of other codes varied, none were nearly as common as elaboration and agreement. A common pattern was to have high numbers of elaboration and agreement, with about half as many codes in the categories of affirmation, question, or summarizing. Groups primarily differed in the number of interactions in the questions, framing, and suggestions codes. A few groups engaged in frequent reframing. One group, for example, had 39 utterances coded as reframing, and 37 as elaboration, with only 14 as agreement. That is, that group used a style of reframing the question or problem as a way to accept and promote new ideas. When discussing ethical decision-making in the context of the lack of resources at the school, one member commented, "Yeah, it's a hard topic to talk to them about, too." We take that commenting to be a reframing of the context of the discussion, acknowledging the challenges of teaching decision-making principles in a disadvantaged environment. In this context, the reframing serves to acknowledge the difficulty of the task, but not to discourage the group's progress.

\section{Discussion}

In contrast to findings from previous studies with elementary and high-school students (e.g., Fall, Webb \& Chudowsky, 2001; Fall, Webb \& Wise, 1997; Webb, 1982), we were surprised to find overwhelming evidence of collaborative, cooperative work among our groups, with extremely low rates of conflict, disagreements or assertions of power. The two most common codes were: "elaboration/building on an idea/adding information" and "agreement," which together accounted for one-third of all interactions.

We were also surprised to find so much commonality in forms of verbal interaction across groups. There were very few differences in relative numbers of codes across groups.

Based on previous studies and personal experiences, we expected to find groups engaging in substantial division of labor, where tasks were assigned to individuals to later be combined to be a group product. In contrast, we found evidence of genuine collaborative work, with a consistent pattern of ideas, elaboration, and agreement. The five most common codes, representing sixty-five percent of all coded interactions, were all collaborative, including elaboration, agreement, social, and affirmations. The code for Challenge to an idea/disagreement yielded only one percent of all codes. The overall picture from this data is of a common effort to perform the assigned tasks. We interpret the differences we did find among groups to indicate differences in styles of interaction. Some groups tended to ask questions and make suggestions, while others had higher rates of elaboration and agreement.

In our a priori development of codes, we expected questions to be a substantial organizing element of the group interactions. Some previous studies of groups of school-age students found questions to be particularly important in understanding the nature of the interactions, for example, which group members asked vs. those who answered, and which group members' questions were ignored by the group (Webb, Farivar \& George, 2002). Those studies showed much more dominance and conflict than were found with this population. In these groups, questions were mostly used in two ways, first, as a way to organize or summarize the content, and second, as a subtle form of leadership. Rather than stating something like, "Next we should work on...," these students would frame their guidance as a question "e.g., "Should we work on...?" or "Do you think we should...?"

The surprising level of substantive collaboration in these groups raises questions for further research. It would be interesting to know how the students themselves thought about their interactions in the groups, what they thought were their goals and their approaches to interacting with one another. It would also be interesting to find out about how those 
students deal with conflict, since conflict was so rare in the interactions we observed.

Possible explanations include:

1. It is a relatively small community in which harmony is valued.

2. Belief in the importance of the task - this wasn't just a classroom task, it was done to help students in the community. Their work would be seen outside the university and could have meaningful impact.

3. Prior work together in other classes.

4. Fear of being removed from the group by other team members.

\section{Limitations}

This study is limited by the use of a sample of students at one private university. Nearly all of the students in the sample were business majors. We surmise that students majoring in business may be particularly motivated, outgoing, and hard-working, compared to other undergraduates, and those aspects of personality might have a meaningful effect on their work in groups. Similar studies of students in other majors, and students with other dispositions, could be illuminating. It is also notable that because the university is explicitly identified as Christian, and many students choose the university based on their faith perspective or faith tradition, it may be that these students' cooperative dispositions exemplify their personal ethical and interpersonal values rather than influences of the curriculum or the public school classroom environments.

\section{Conclusion}

This study of undergraduate business students' interaction in cooperative groups produced some unexpected results. In contrast to previous studies, these students showed very high levels of cooperation. While undergraduate students in cooperative groups often divide and assign tasks, these students chose to work collaboratively. Their overwhelming use of verbalizations in the categories of agreement, affirmation and elaboration are evidence of groups that functioned in a very focused and collaborative way. We hypothesize that the purpose of their group work was one key element in the collaborative character of their interactions. That is, they were focused on creating engaging, effective lessons for the public school students they served, and they understood the group work as the most effective way to accomplish that goal.

Future studies could focus on defining expected norms for verbal interaction among groups of young adults, perhaps comparing individuals of similar ages in different contexts. The consistency of forms of interaction among these students seems to imply that powerful social expectations are at work. It would be illustrative to discover how young adults experience and characterize those social forces.

\section{Acknowledgements}

The authors would like to acknowledge Madison Nelson, UG Research Assistant, for providing video-taping supervision and Ella O'Neil and Kidist Bremer-Bennett, UG Research Assistants, for their work in coding group interactions.

\section{References}

Bales, R. F. (1958). Task roles and social roles in problem-solving groups. In E. E. Maccoby, T. M. Newcomb and E. L. Hartley (eds.), Readings in social psychology (pp 437-447). New York: Henry Holt.

Battistich, V., et al. (1993). Interaction processes and student outcomes in cooperative learning groups. The Elementary School Journal, 94(1): 19-32. https://doi.org/10.1086/461748

Brickner, M. A., Harkins, S. G., \& Ostrom, T. M. (1986). Effects of personal involvement: Thought provoking implications for social loafing. Journal of Personality and Social Psychology, 51, 763-769. https://doi.org/10.1037/0022-3514.51.4.763

Burke, C. S., Fiore, S. M., \& Salas, E. (2003). The role of shared cognition in enabling shared leadership and team adaptability. In Pearce, C. L. \& Conger, J. A. (Eds.). Shared leadership: Reframing the hows and whys of leadership (pp. 103-122). Sage: Thousand Oaks. https://doi.org/10.4135/9781452229539.n5

Carless, S. A., \& De Paola, C. (2000). A measurement of cohesion in work teams. Small Group Research, 31(1), 71-88. https://doi.org/10.1177/104649640003100104

Carson, J. B., Tesluk, P. E., \& Marrone, J. A. (2007). Shared leadership in teams: An investigation of antecedent conditions and performance. Academy of Management Journal, 50(4), 1217-1234. https://doi.org/10.2307/20159921

Chiu, C. Y. C., Owens, B. P., \& Tesluk, P. E. (2016). Initiating and utilizing shared leadership in teams: The role of 
leader humility, team proactive personality and team performance capability. Journal of Applied Psychology, 101, 1707-1720. https://doi.org/10.1037/ap10000159

Cook, K. S., Hardin, R., \& Levi, M. (2005). Cooperation without trust? New York: Russell Sage Foundation.

D’Innocenzo, L., Matheiu, J. E., \& Kukenberger, M. R. (2016). A meta-analysis of different forms of shared leadership-team performance relations. Journal of Management, 42(7), 1964-1991. https://doi.org/10.1177/0149206314525205

Daspit, J., Tillman, C. J., Boyd, N. G., \& McKee, V. (2013). Cross-functional team effectiveness: An examination of internal team environment, shared leadership, and cohesion influences. Team Performance Management, 19(1/2), 34-56. https://doi.org/10.1108/13527591311312088

Dickerson, M. S., Helm-Stevens, R., \& Fall, R. (2017). Service-learning in business education: An analysis of spirituality, leadership and motivation. American Journal of Economics and Business Administration, 9(1), 1-12. https://doi.org/10.3844/ajebasp.2017.1.12

Dickson, M. W., Resick, C. J., \& Hanges, P. J. (2006). Systematic variation in organizationally-shared cognitive prototypes of effective leadership based on organizational form. The Leadership Quarterly, 17(5), 487-505. https://doi.org/10.1016/j.leaqua.2006.07.005

Ensari, N. Riggio, R. E. Christian, J., \& Carslaw, G. (2011). Who emerges as a leader? Meta-analyses of individual differences as predictors of leadership emergence. Personality and Individual Differences, 51(4), 532-536. https://doi.org/10.1016/j.paid.2011.05.017

Eyler, J., \& Giles, D. E. (1999). Where's the learning in service learning? San Francisco, John Wiley \& Sons.

Falk, A. (2012). Enhancing the team experience in service-learning courses. The Journal for Civic Commitment, 18.

Fall, R., Webb, N. M., \& Chudowsky, N. (2000). Group discussion and large-scale language arts assessment: Effects on students' comprehension. American Educational Research Journal, 37, 911-942.

Fall, R., Webb, N. M., \& Wise, N. (1997). Group discussion and large-scale language arts assessment: Effects on students' comprehension. (Tech. Rep. No. 455). Los Angeles: University of California, Los Angeles, Center for Research on Evaluation, Standards and Student Testing. https://doi.org/10.1037/e651442011-001

Fausing, M. S., Joensson, T. S., Lewandowski, J., \& Bligh, M. (2015). Antecedents of shared leadership: Empowering leadership and interdependence. Leadership \& Organization Development Journal, 36(3), 271-291. https://doi.org/10.1108/LODJ-06-2013-0075

Foli, K. J., et al. (2014). "Development of leadership behaviors in undergraduate nursing students: A service-learning approach." Nursing Education Perspectives 35(2), 76-82. https://doi.org/10.5480/11-578.1

Franz, T. M. (2012). Group dynamics and team interventions: Understanding and improving team performance. Malden, MA: Wiley-Blackwell.

Gallo-Fox, J., \& Scantlebury, K. (2015). "It isn’t necessarily sunshine and daisies every time": coplanning opportunities and challenges when student teaching. Asia-Pacific Journal of Teacher Education, 43(4), 324-337. https://doi.org/10.1080/1359866X.2015.1060294

George, J. M. (1992). Extrinsic and intrinsic origins of perceived social loafing in organizations. Academy of Management Journal, 35(1), 191-202. https://doi.org/10.5465/256478

Grille, A., Schulte, E., \& Kauffeld, S. (2015). Promoting shared leadership: A multilevel analysis investigating the role of prototypical team leader behavior, psychological empowerment, and fair rewards. Journal of Leadership \& Organizational Studies, 22, 324-339. https://doi.org/10.1177/1548051815570039

Hackman, J. R. (1987). The design of work teams. In J. W. Lorsch (Ed.), Handbook of organizational behavior (pp. 315-342). Englewood Cliffs, NJ: Prentice Hall.

Hackman, R. (1986). The psychology of self-management in organizations: Productivity, change and employment. In Psychology and work, M. Pallak and R. Perloff (Eds.). Washington, D.C., American Psychological Association.

Harkins, S. G. M., \& Petty, R. E. (1982). Effects of task difficulty and task uniqueness on social loafing. Journal of Personality and Social Psychology, 43, 1214-1230. https://doi.org/10.1037/0022-3514.43.6.1214

Harkins, S. G., \& Szymanski, K. (1989). Social loafing and group evaluation. Journal of Personality and Social Psychology, 56, 939-941. https://doi.org/10.1037/0022-3514.56.6.934 
Harkins, S., \& Jackson, J. (1985). The role of evaluation in eliminating social loafing. Personality and Social Psychology Bulletin, 11, 457-465. https://doi.org/10.1177/0146167285114011

Helm-Stevens, R. and O. Griego (2009). Evaluating experiential learning in organizational behavior: Taking measure of student perception regarding group experience. American Journal of Economics and Business Administration, 1(2), 138-140. https://doi.org/10.3844/ajebasp.2009.138.140

Hoch, J. E. (2013). Shared leadership and innovation: The role of vertical leadership and employee integrity. Journal of Business and Psychology, 28, 159-174. https://doi.org/10.1007/s10869-012-9273-6

Hoch, J. E. (2014). Shared leadership, diversity, and information sharing in teams. Journal of Managerial Psychology, 29(5), 541-564. https://doi.org/10.1108/JMP-02-2012-0053

Jehn, K. A. (1995). A multimethod examination of the benefits and detriments of intragroup conflict. Administrative Science Quarterly, 40(2), 256-282. https://doi.org/10.2307/2393638

Jehn, K. A., Northcraft, G. B., \& Neale, M. A. (1999). Why differences make a difference. A field study of diversity, conflict and performance in workgroups. Administrative Science Quarterly, 44(4), 741-763. https://doi.org/10.2307/2667054

Johnson, D. W., \& Johnson, F. P. (2009). Joining together: Group theory and group skills. Upper Saddle River, NJ, Pearson.

Johnson, R. T., \& Johnson, D. W. (1994). An overview of cooperative learning. In Creativity and Collaborative Learning, J. Thousand, A. Villa and A. Nevin. Baltimore, MD, Brookes Press.

Johnson, U. W., et al. (1990). Impact of group processing on achievement in cooperative groups. Journal of Social Psychology 130, 507-516. https://doi.org/10.1080/00224545.1990.9924613

Karau, S., \& Williams, K. (1993). Social loafing: A meta-analytic review and theoretical integration. Journal of Personality and Social Psychology, 65, 681-706. https://doi.org/10.1037/0022-3514.65.4.681

Karau, S., \& Williams, K. (1997). The effects of group cohesion on social loafing and social compensation. Group Dynamics: Theory, Research and Practice, 1, 156-168. https://doi.org/10.1037/1089-2699.1.2.156

Komives, S. R., et al. (2005). Developing a leadership identity: A grounded theory. Journal of College Student Development 46(6), 593-611. https://doi.org/10.1353/csd.2005.0061

Kwok, N., Hanig, S., Brown, D. J., \& Shen, W. (2018). How leader role identity influences the process of leader emergence: A social network analysis. The Leadership Quarterly, 29(6), 648-662. https://doi.org/10.1016/j.leaqua.2018.04.003

Lester, S. W. (2015). "Melding service learning and leadership skills development: Keys to effective course design." Journal of Experiential Education, 38(3), 280-295. https://doi.org/10.1177/1053825915576196

Liden, R., Wayne, S. J., Jaworski, R. A., \& Bennett, N. (2004). Social loafing: A field investigation. Journal of Management, 30(2), 285-311. https://doi.org/10.1016/j.jm.2003.02.002

Muethel, M., Gehrlein, S., \& Hoegl, M. (2012). Sociodemographic factors and shared leadership behaviors in dispersed teams: Implications for human resource management. Human Resource Management, 51(4), 525-548. https://doi.org/10.1002/hrm.21488

Nijhuis, B. J. G., Reinders-Messelink, H. A., de Blecourt, A. C. E., Olijve, W. G., Groothoff, J. W., Nakken, H., \& Postema, K. (2007). A review of salient elements defining team collaboration in paediatric rehabilitation. Clinical Rehabilitation, 21, 195-211. https://doi.org/10.1177/0269215506070674

Pearce, C. L., \& Conger, J. A. (2003a). All those years ago. The historical underpinnings of shared leadership. In Pearce, C. L. \& Conger, J. A. (Eds.). Shared leadership: Reframing the hows and whys of leadership (pp. 1-18). Sage: Thousand Oaks. https://doi.org/10.4135/9781452229539.n1

Pearce, C. L., \& Conger, J. A. (Eds.) (2003b). Shared leadership: Reframing the hows and whys of leadership. Sage: Thousand Oaks.

Petersen, N., \& Gadija, P. (2017). Teacher education students' struggles with group work in service learning. South African Journal of Childhood Education, 7(1), a479. https://doi.org/10.4102/sajce.v7i1.479

Raskoff, S. (1997). Group dynamics in service-learning: Guiding student relations. Michigan Journal of Community Service Learning, 109-115.

Scribner, J. P., Sawyer, R. K., Watson, S. T., \& Myers, V. L. (2007). Teacher teams and distributed leadership: A study of 
group discourse and collaboration. Educational Administration Quarterly, 43(1), 67-100. https://doi.org/10.1177/0013161X06293631

Seers, A., Keller, T., \& Wilkerson, J. M. (2003). Can team members share leadership? Foundations in research and theory. In C. L. Pearce \& J. A. Conger (eds.), Shared leadership: Reframing the hows and whys of leadership (pp. 77-102). Sage: Thousand Oaks. https://doi.org/10.4135/9781452229539.n4

Serban, A., \& Roberts, A. J. (2016). Exploring antecedents and outcomes of shared leadership in a creative context: A mixed methods approach. The Leadership Quarterly, 27, 181-199. https://doi.org/10.1016/j.leaqua.2016.01.009

Slater, P. E. (1955). Role differentiation in small groups. American Sociology Journal, $20,300-310$. https://doi.org/10.2307/2087389

Slavin, R. (1989). Cooperative learning and student achievement. In R. Slavin (Ed.), School and classroom organization (pp. 129-156). New Jersey: Lawrence Erlbaum. https://doi.org/10.4324/9780203056950-5

Small, E. E. \& Rentsch, J. R. (2010). Shared leadership in teams: A matter of distribution. Journal of Personal Psychology, 9(4), 203-211. https://doi.org/10.1027/1866-5888/a000017

Stenhouse, V. L. and O. S. Jarrett (2012). In the service of learning and activism: Service learning, critical pedagogy, and the problem solution project. Teacher Education Quarterly, 51-76.

Szymanski, K., \& Harkins, S. G. (1987). Social loafing and self-evaluation with a social standard. Journal of Personality and Social Psychology, 53, 891-897. https://doi.org/10.1037/0022-3514.53.5.891

Tjosvold, D. (1986). Working together to get things done: Managing for organizational productivity. Lexington, MA: Lexington Books, D. C. Heath \& Company.

Tjosvold, D. (1988). Cooperative and competitive dynamics within and between organizational units. Human Relations, 41(6), 425-437. https://doi.org/10.1177/001872678804100601

Tjosvold, D. (1995). Cooperation theory, constructive controversy, and effectiveness: Learning from crisis. In R. A. Guzzo \& E. Salas (Eds.), Team effectiveness and decision making in organizations. San Francisco: Jossey-Bass Publishers.

Van der Vegt, G., et al. (1998). Motivating effects of task and outcome interdependence. Group and Organization Management, 23, 124-144. https://doi.org/10.1177/1059601198232003

Vaughn, M. S. (2010). Finding the value in group projects: Service learning in a group communication course. The Journal for Civic Commitment, 15.

Webb, N. M. (1982). Student interaction and learning in small groups. Review of Educational Research, 52(3), $421-445$. https://doi.org/10.3102/00346543052003421

Webb, N. M., Troper, J. D., \& Fall, R. (1995). Constructive activity and learning in collaborative small groups. Journal of Educational Psychology, 87, 406-423. https://doi.org/10.1037/0022-0663.87.3.406

Webb, N., Farivar, S., \& Mastergeorge, A. (2002). Productive helping in cooperative groups. Theory Into Practice, 41. 13-20. https://doi.org/10.1207/s15430421tip4101_3

Williams, K. D., Harkins, S. G., \& Latane, B. (1981). Identifiability as a deterrent to social loafing: Two cheering experiments. Journal of Personality and Social Psychology, 40, 303-311. https://doi.org/10.1037/0022-3514.40.2.303

Wilson, J. M., et al. (2007). Group learning. The Academy of Management Review, 32(4), 1041-1059. https://doi.org/10.5465/amr.2007.26585724

Wu, Q., Cormican, K., \& Chen, G. (2018). A meta-analysis of shared leadership: Antecedents, consequences, and moderators. Journal of Leadership and Organizational Studies, 1-16. https://doi.org/10.1177/1548051818820862

Wurr, A. J., \& Hamilton, C. H. (2012). Leadership development in service-learning: An exploratory investigation. Journal of Higher Education Outreach and Engagement 16(2), 213-239.

Yelsma, P. (1999). Small group problem solving as academic service-learning. In Voices of strong democracy: Concepts and models for service learning in communication studies, D. Droge and B. O. Murphy. Washington, D.C.: American Association for Higher Education.

Zlotkowski, E., et al., eds. (2006). Students as colleagues: Expanding the circle of service-learning leadership. Providence, RI: Campus Compact. 
Tables

\begin{tabular}{|c|c|c|c|c|}
\hline \multicolumn{5}{|c|}{ \$CO01929mr Frequencies } \\
\hline & & \multicolumn{2}{|c|}{ Responses } & \multirow[b]{2}{*}{ Percent of Cases } \\
\hline & & $\mathrm{N}$ & Percent & \\
\hline \multirow[t]{8}{*}{ Charter Oak 1 9/29a } & 1 & 2 & $4.4 \%$ & $4.8 \%$ \\
\hline & 2 & 10 & $22.2 \%$ & $23.8 \%$ \\
\hline & 4 & 2 & $4.4 \%$ & $4.8 \%$ \\
\hline & 5 & $1 \overline{5}$ & $33.3 \%$ & $35.7 \%$ \\
\hline & 6 & 4 & $8.9 \%$ & $9.5 \%$ \\
\hline & 7 & 5 & $11.1 \%$ & $11.9 \%$ \\
\hline & 8 & 4 & $8.9 \%$ & $9.5 \%$ \\
\hline & 10 & 3 & $6.7 \%$ & $7.1 \%$ \\
\hline Total & & 45 & $100.0 \%$ & $107.1 \%$ \\
\hline
\end{tabular}

a. Group

\begin{tabular}{|c|c|c|c|c|}
\hline \multicolumn{5}{|c|}{ \$CO20929mr Frequencies } \\
\hline & & \multicolumn{2}{|c|}{ Responses } & \multirow[b]{2}{*}{ Percent of Cases } \\
\hline & & $\mathrm{N}$ & Percent & \\
\hline \multirow[t]{12}{*}{ Charter Oak 2 9/29a } & 1 & 4 & $3.3 \%$ & $3.4 \%$ \\
\hline & 2 & 21 & $17.1 \%$ & $17.8 \%$ \\
\hline & 3 & 7 & $5.7 \%$ & $5.9 \%$ \\
\hline & 4 & 5 & $4.1 \%$ & $4.2 \%$ \\
\hline & 5 & 44 & $35.8 \%$ & $37.3 \%$ \\
\hline & 6 & 3 & $2.4 \%$ & $2.5 \%$ \\
\hline & 7 & 2 & $1.6 \%$ & $1.7 \%$ \\
\hline & 8 & 10 & $8.1 \%$ & $8.5 \%$ \\
\hline & 9 & 1 & $0.8 \%$ & $0.8 \%$ \\
\hline & 10 & 7 & $5.7 \%$ & $5.9 \%$ \\
\hline & 11 & 16 & $13.0 \%$ & $13.6 \%$ \\
\hline & 12 & 3 & $2.4 \%$ & $2.5 \%$ \\
\hline Total & & 123 & $100.0 \%$ & $104.2 \%$ \\
\hline
\end{tabular}

a. Group

\section{\$C030929mr Frequencies}

\begin{tabular}{|c|c|c|c|c|}
\hline \multicolumn{5}{|c|}{ \$C030929mr Frequencies } \\
\hline & & \multicolumn{2}{|c|}{ Responses } & \multirow[b]{2}{*}{ Percent of Cases } \\
\hline & & $\mathrm{N}$ & Percent & \\
\hline Charter Oak 3 9/29a & 1 & 4 & $3.5 \%$ & $3.5 \%$ \\
\hline & 2 & 18 & $15.7 \%$ & $15.9 \%$ \\
\hline & 3 & 2 & $1.7 \%$ & $1.8 \%$ \\
\hline & 4 & 8 & $7.0 \%$ & $7.1 \%$ \\
\hline & 5 & 38 & $33.0 \%$ & $33.6 \%$ \\
\hline & 6 & 7 & $6.1 \%$ & $6.2 \%$ \\
\hline & 7 & 2 & $1.7 \%$ & $1.8 \%$ \\
\hline & 8 & 3 & $2.6 \%$ & $2.7 \%$ \\
\hline & 9 & 3 & $2.6 \%$ & $2.7 \%$ \\
\hline & 10 & 26 & $22.6 \%$ & $23.0 \%$ \\
\hline & 11 & 4 & $3.5 \%$ & $3.5 \%$ \\
\hline Total & & 115 & $100.0 \%$ & $101.8 \%$ \\
\hline
\end{tabular}

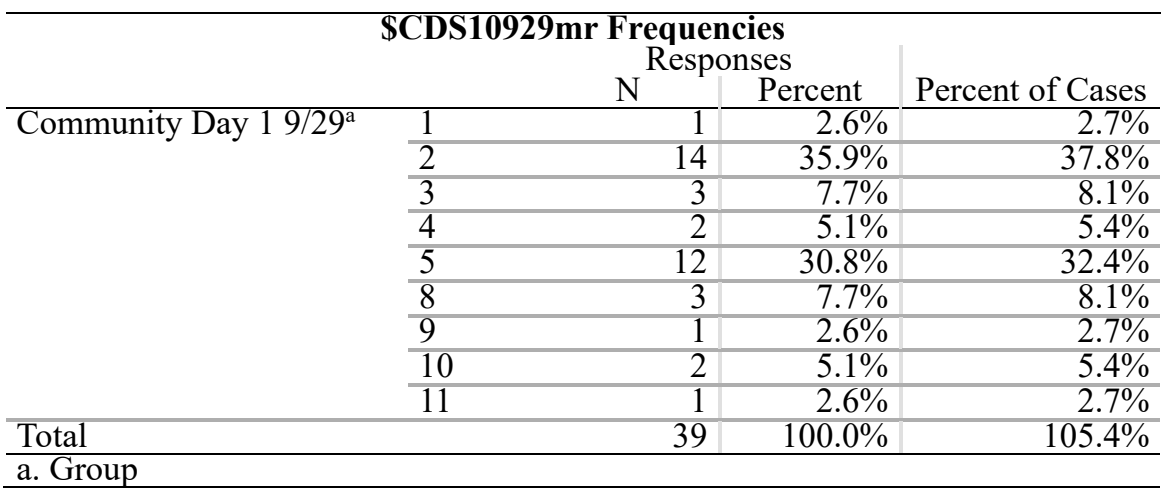


\$WH40929ml Frequencies

\begin{tabular}{|c|c|c|c|c|}
\hline \multicolumn{5}{|c|}{ \$WH40929ml Frequencies } \\
\hline & & \multicolumn{2}{|c|}{ Responses } & \multirow[b]{2}{*}{ Percent of Cases } \\
\hline & & $\mathrm{N}$ & Percent & \\
\hline \multirow[t]{12}{*}{ Whitman $49 / 29^{a}$} & 1 & 2 & $1.5 \%$ & $1.5 \%$ \\
\hline & 2 & 37 & $27.8 \%$ & $28.2 \%$ \\
\hline & 3 & 7 & $5.3 \%$ & $5.3 \%$ \\
\hline & 4 & 5 & $3.8 \%$ & $3.8 \%$ \\
\hline & 5 & 39 & $29.3 \%$ & $29.8 \%$ \\
\hline & 6 & 2 & $1.5 \%$ & $1.5 \%$ \\
\hline & 7 & 4 & $3.0 \%$ & $3.1 \%$ \\
\hline & 8 & 14 & $10.5 \%$ & $10.7 \%$ \\
\hline & 9 & 1 & $0.8 \%$ & $0.8 \%$ \\
\hline & 10 & 16 & $12.0 \%$ & $12.2 \%$ \\
\hline & 11 & 3 & $2.3 \%$ & $2.3 \%$ \\
\hline & 12 & 3 & $2.3 \%$ & $2.3 \%$ \\
\hline Total & & 133 & $100.0 \%$ & $101.5 \%$ \\
\hline a. Group & & & & \\
\hline
\end{tabular}

\$WH40929CDEmr Frequencies

\begin{tabular}{|c|c|c|c|c|}
\hline \multicolumn{5}{|c|}{ \$WH40929CDEmr Frequencies } \\
\hline & & \multicolumn{2}{|c|}{ Responses } & \multirow[b]{2}{*}{ Percent of Cases } \\
\hline & & $\mathrm{N}$ & Percent & \\
\hline \multirow[t]{9}{*}{ Whitman $409 / 29^{\mathrm{a}}$} & 1 & 1 & $2.5 \%$ & $2.6 \%$ \\
\hline & 2 & 9 & $22.5 \%$ & $23.1 \%$ \\
\hline & 3 & 3 & $7.5 \%$ & $7.7 \%$ \\
\hline & 4 & 3 & $7.5 \%$ & $7.7 \%$ \\
\hline & 5 & 9 & $22.5 \%$ & $23.1 \%$ \\
\hline & 6 & 1 & $2.5 \%$ & $2.6 \%$ \\
\hline & 8 & 3 & $7.5 \%$ & $7.7 \%$ \\
\hline & 9 & 1 & $2.5 \%$ & $2.6 \%$ \\
\hline & 10 & 10 & $25.0 \%$ & $25.6 \%$ \\
\hline Total & & 40 & $100.0 \%$ & $102.6 \%$ \\
\hline
\end{tabular}

\section{a. Group}

\begin{tabular}{|c|c|c|c|c|}
\hline \multicolumn{5}{|c|}{ \$WH30929ml Frequencies } \\
\hline & & \multicolumn{2}{|c|}{ Responses } & \multirow[b]{2}{*}{ Percent of Cases } \\
\hline & & $\mathrm{N}$ & Percent & \\
\hline \multirow[t]{10}{*}{ Whtcomb3 9/29a } & 1 & 1 & $1.7 \%$ & $1.7 \%$ \\
\hline & 2 & 11 & $19.0 \%$ & $19.0 \%$ \\
\hline & 3 & 3 & $5.2 \%$ & $5.2 \%$ \\
\hline & 4 & 4 & $6.9 \%$ & $6.9 \%$ \\
\hline & 5 & 11 & $19.0 \%$ & $19.0 \%$ \\
\hline & 6 & 3 & $5.2 \%$ & $5.2 \%$ \\
\hline & 8 & 8 & $13.8 \%$ & $13.8 \%$ \\
\hline & 9 & 1 & $1.7 \%$ & $1.7 \%$ \\
\hline & 10 & 13 & $22.4 \%$ & $22.4 \%$ \\
\hline & 11 & 3 & $5.2 \%$ & $5.2 \%$ \\
\hline Total & & 58 & $100.0 \%$ & $100.0 \%$ \\
\hline
\end{tabular}




\begin{tabular}{|c|c|c|c|c|}
\hline \multicolumn{5}{|c|}{ \$C011013 Frequencies } \\
\hline & & \multicolumn{2}{|c|}{ Responses } & \multirow[b]{2}{*}{ Percent of Cases } \\
\hline & & $\mathrm{N}$ & Percent & \\
\hline \multirow[t]{10}{*}{ CO $110 / 13^{\mathrm{a}}$} & 1 & 1 & $0.9 \%$ & $1.0 \%$ \\
\hline & 2 & 17 & $15.9 \%$ & $16.5 \%$ \\
\hline & 3 & 10 & $9.3 \%$ & $9.7 \%$ \\
\hline & 4 & 12 & $11.2 \%$ & $11.7 \%$ \\
\hline & 5 & 24 & $22.4 \%$ & $23.3 \%$ \\
\hline & 6 & 4 & $3.7 \%$ & $3.9 \%$ \\
\hline & 7 & 9 & $8.4 \%$ & $8.7 \%$ \\
\hline & 8 & 5 & $4.7 \%$ & $4.9 \%$ \\
\hline & 9 & 8 & $7.5 \%$ & $7.8 \%$ \\
\hline & 10 & 17 & $15.9 \%$ & $16.5 \%$ \\
\hline Total & & 107 & $100.0 \%$ & $103.9 \%$ \\
\hline a. Group & & & & \\
\hline
\end{tabular}

\begin{tabular}{|c|c|c|c|c|}
\hline \multicolumn{5}{|c|}{ \$CO31013ml Frequencies } \\
\hline & & \multicolumn{2}{|c|}{ Responses } & \multirow[b]{2}{*}{ Percent of Cases } \\
\hline & & $\mathrm{N}$ & Percent & \\
\hline \multirow[t]{11}{*}{$\operatorname{CO} 310 / 13^{a}$} & 1 & 2 & $1.7 \%$ & $1.7 \%$ \\
\hline & 2 & 20 & $16.7 \%$ & $16.7 \%$ \\
\hline & 3 & 6 & $5.0 \%$ & $5.0 \%$ \\
\hline & 4 & 17 & $14.2 \%$ & $14.2 \%$ \\
\hline & 5 & 18 & $15.0 \%$ & $15.0 \%$ \\
\hline & 6 & 5 & $4.2 \%$ & $4.2 \%$ \\
\hline & 7 & 2 & $1.7 \%$ & $1.7 \%$ \\
\hline & 8 & 16 & $13.3 \%$ & $13.3 \%$ \\
\hline & 10 & 17 & $14.2 \%$ & $14.2 \%$ \\
\hline & 11 & 3 & $2.5 \%$ & $2.5 \%$ \\
\hline & 13 & 14 & $11.7 \%$ & $11.7 \%$ \\
\hline Total & & 120 & $100.0 \%$ & $100.0 \%$ \\
\hline \multicolumn{5}{|c|}{ a. Group } \\
\hline
\end{tabular}

\begin{tabular}{|c|c|c|c|c|c|c|}
\hline \multicolumn{7}{|c|}{ Case Summary } \\
\hline & \multirow{2}{*}{\multicolumn{2}{|c|}{ Valid }} & \multirow{2}{*}{\multicolumn{2}{|c|}{$\begin{array}{l}\text { Cases } \\
\text { Missing }\end{array}$}} & & \\
\hline & & & & & \multicolumn{2}{|c|}{ Total } \\
\hline & $\mathrm{N}$ & Percent & $\mathrm{N}$ & Percent & $\mathrm{N}$ & Percent \\
\hline \$CO01929mr ${ }^{\mathrm{a}}$ & 42 & $16.7 \%$ & 210 & $83.3 \%$ & 252 & $100.0 \%$ \\
\hline$\$ C O 20929 \mathrm{mr}^{\mathrm{a}}$ & 118 & $46.8 \%$ & 134 & $53.2 \%$ & 252 & $100.0 \%$ \\
\hline$\$ C O 30929 m r^{\mathrm{a}}$ & 113 & $44.8 \%$ & 139 & $55.2 \%$ & 252 & $100.0 \%$ \\
\hline \$CDS10929mr & 37 & $14.7 \%$ & 215 & $85.3 \%$ & 252 & $100.0 \%$ \\
\hline \$WH40929ml ${ }^{\mathrm{a}}$ & 131 & $52.0 \%$ & 121 & $48.0 \%$ & 252 & $100.0 \%$ \\
\hline \$WH40929CDEmr ${ }^{\mathrm{a}}$ & 39 & $15.5 \%$ & 213 & $84.5 \%$ & 252 & $100.0 \%$ \\
\hline \$WH30929ml $\mathrm{a}^{\mathrm{a}}$ & 58 & $23.0 \%$ & 194 & $77.0 \%$ & 252 & $100.0 \%$ \\
\hline$\$ C O 11013^{a}$ & 103 & $40.9 \%$ & 149 & $59.1 \%$ & 252 & $100.0 \%$ \\
\hline$\$ C O 31013 \mathrm{ml}^{\mathrm{a}}$ & 120 & $47.6 \%$ & 132 & $52.4 \%$ & 252 & $100.0 \%$ \\
\hline \$CO11013mr ${ }^{\mathrm{a}}$ & 103 & $40.9 \%$ & 149 & $59.1 \%$ & 252 & $100.0 \%$ \\
\hline$\$ S I 11013 m r^{\mathrm{a}}$ & 186 & $73.8 \%$ & 66 & $26.2 \%$ & 252 & $100.0 \%$ \\
\hline \$SI21013mr ${ }^{\mathrm{a}}$ & 175 & $69.4 \%$ & 77 & $30.6 \%$ & 252 & $100.0 \%$ \\
\hline \$WH11013mr ${ }^{\mathrm{a}}$ & 170 & $67.5 \%$ & 82 & $32.5 \%$ & 252 & $100.0 \%$ \\
\hline$\$ W H 21013 \mathrm{mr}^{\mathrm{b}}$ & 1 & $0.4 \%$ & 251 & $99.6 \%$ & 252 & $100.0 \%$ \\
\hline \$WH41013mr & 125 & $49.6 \%$ & 127 & $50.4 \%$ & 252 & $100.0 \%$ \\
\hline \$WH51013mr & 60 & $23.8 \%$ & 192 & $76.2 \%$ & 252 & $100.0 \%$ \\
\hline$\$ C 021020 m^{a}$ & 117 & $46.4 \%$ & 135 & $53.6 \%$ & 252 & $100.0 \%$ \\
\hline$\$ C O 41020 \mathrm{mr}^{\mathrm{a}}$ & 33 & $13.1 \%$ & 219 & $86.9 \%$ & 252 & $100.0 \%$ \\
\hline \$CD11020mr ${ }^{\mathrm{a}}$ & 111 & $44.0 \%$ & 141 & $56.0 \%$ & 252 & $100.0 \%$ \\
\hline \$CD11013mr ${ }^{\mathrm{a}}$ & 95 & $37.7 \%$ & 157 & $62.3 \%$ & 252 & $100.0 \%$ \\
\hline
\end{tabular}

\section{a. Group}

b. Dichotomy group tabulated at value 1 . 


\begin{tabular}{|c|c|c|c|c|}
\hline & \multicolumn{3}{|c|}{$\begin{array}{c}\text { \$CO11013mr Frequencies } \\
\text { Responses }\end{array}$} & \multirow[b]{2}{*}{ Percent of Cases } \\
\hline & & $\mathrm{N}$ & Percent & \\
\hline \multirow[t]{10}{*}{$\operatorname{CO} 110 / 13^{a}$} & 1 & 1 & $0.9 \%$ & $1.0 \%$ \\
\hline & 2 & 17 & $15.9 \%$ & $16.5 \%$ \\
\hline & 3 & 10 & $9.3 \%$ & $9.7 \%$ \\
\hline & 4 & 12 & $11.2 \%$ & $11.7 \%$ \\
\hline & 5 & 24 & $22.4 \%$ & $23.3 \%$ \\
\hline & 6 & 4 & $3.7 \%$ & $3.9 \%$ \\
\hline & 7 & 9 & $8.4 \%$ & $8.7 \%$ \\
\hline & 8 & 5 & $4.7 \%$ & $4.9 \%$ \\
\hline & 9 & 8 & $7.5 \%$ & $7.8 \%$ \\
\hline & 10 & 17 & $15.9 \%$ & $16.5 \%$ \\
\hline Total & & 107 & $100.0 \%$ & $103.9 \%$ \\
\hline
\end{tabular}

a. Group

\begin{tabular}{|c|c|c|c|c|}
\hline \multicolumn{5}{|c|}{ \$SI11013mr Frequencies } \\
\hline & & $\mathrm{N}$ & Percent & Percent of Cases \\
\hline \multirow[t]{13}{*}{ Sierra $110 / 13^{a}$} & 1 & 1 & $0.5 \%$ & $0.5 \%$ \\
\hline & 2 & 14 & $7.5 \%$ & $7.5 \%$ \\
\hline & 3 & 13 & $7.0 \%$ & $7.0 \%$ \\
\hline & 4 & 39 & $20.9 \%$ & $21.0 \%$ \\
\hline & 5 & 37 & $19.8 \%$ & $19.9 \%$ \\
\hline & 6 & 17 & $9.1 \%$ & $9.1 \%$ \\
\hline & 7 & 8 & $4.3 \%$ & $4.3 \%$ \\
\hline & 8 & 10 & $5.3 \%$ & $5.4 \%$ \\
\hline & 9 & 2 & $1.1 \%$ & $1.1 \%$ \\
\hline & 10 & 21 & $11.2 \%$ & $11.3 \%$ \\
\hline & 11 & 2 & $1.1 \%$ & $1.1 \%$ \\
\hline & 13 & 11 & $5.9 \%$ & $5.9 \%$ \\
\hline & 14 & 12 & $6.4 \%$ & $6.5 \%$ \\
\hline Total & & 187 & $100.0 \%$ & $100.5 \%$ \\
\hline
\end{tabular}

a. Group

\begin{tabular}{|c|c|c|c|c|}
\hline \multicolumn{5}{|c|}{ \$SI21013mr Frequencies } \\
\hline & & \multicolumn{2}{|c|}{ Responses } & \multirow[b]{2}{*}{ Percent of Cases } \\
\hline & & $\mathrm{N}$ & Percent & \\
\hline \multirow[t]{13}{*}{ Sierra $210 / 13^{a}$} & 1 & 1 & $0.6 \%$ & $0.6 \%$ \\
\hline & 2 & 35 & $19.6 \%$ & $20.0 \%$ \\
\hline & 3 & 12 & $6.7 \%$ & $6.9 \%$ \\
\hline & 4 & 23 & $12.8 \%$ & $13.1 \%$ \\
\hline & 5 & 23 & $12.8 \%$ & $13.1 \%$ \\
\hline & 6 & 5 & $2.8 \%$ & $2.9 \%$ \\
\hline & 7 & 1 & $0.6 \%$ & $0.6 \%$ \\
\hline & 8 & 10 & $5.6 \%$ & $5.7 \%$ \\
\hline & 9 & 2 & $1.1 \%$ & $1.1 \%$ \\
\hline & 10 & 25 & $14.0 \%$ & $14.3 \%$ \\
\hline & 12 & 18 & $10.1 \%$ & $10.3 \%$ \\
\hline & 13 & 15 & $8.4 \%$ & $8.6 \%$ \\
\hline & 14 & 9 & $5.0 \%$ & $5.1 \%$ \\
\hline Total & & 179 & $100.0 \%$ & $102.3 \%$ \\
\hline
\end{tabular}

a. Group 


\begin{tabular}{|c|c|c|c|c|}
\hline \multicolumn{5}{|c|}{ \$WH11013mr Frequencies } \\
\hline & & \multicolumn{2}{|c|}{ Responses } & \multirow[b]{2}{*}{ Percent of Cases } \\
\hline & & $\mathrm{N}$ & Percent & \\
\hline \multirow[t]{12}{*}{ Whitcomb 1 10/13 ${ }^{\mathrm{a}}$} & 1 & 1 & $0.6 \%$ & $0.6 \%$ \\
\hline & 2 & 29 & $16.9 \%$ & $17.1 \%$ \\
\hline & 3 & 12 & $7.0 \%$ & $7.1 \%$ \\
\hline & 4 & 29 & $16.9 \%$ & $17.1 \%$ \\
\hline & 5 & 30 & $17.4 \%$ & $17.6 \%$ \\
\hline & 6 & 8 & $4.7 \%$ & $4.7 \%$ \\
\hline & 7 & 3 & $1.7 \%$ & $1.8 \%$ \\
\hline & 8 & 20 & $11.6 \%$ & $11.8 \%$ \\
\hline & 9 & 1 & $0.6 \%$ & $0.6 \%$ \\
\hline & 10 & 22 & $12.8 \%$ & $12.9 \%$ \\
\hline & 13 & 11 & $6.4 \%$ & $6.5 \%$ \\
\hline & 14 & 6 & $3.5 \%$ & $3.5 \%$ \\
\hline Total & & 172 & $100.0 \%$ & $101.2 \%$ \\
\hline
\end{tabular}

a. Group

\section{\$WH21013mr Frequencies}

\begin{tabular}{|c|c|c|c|c|}
\hline & & \multicolumn{2}{|c|}{ Responses } & \multirow[b]{2}{*}{ Percent of Cases } \\
\hline & & $\mathrm{N}$ & Percent & \\
\hline Whitcomb2 10/13a & WH21013_D & $\overline{1}$ & $100.0 \%$ & $100.0 \%$ \\
\hline Total & & 1 & $100.0 \%$ & $100.0 \%$ \\
\hline
\end{tabular}

a. Dichotomy group tabulated at value 1 .

\begin{tabular}{|c|c|c|c|c|}
\hline \multicolumn{5}{|c|}{ \$WH41013mr Frequencies } \\
\hline & & \multicolumn{2}{|c|}{ Responses } & \multirow[b]{2}{*}{ Percent of Cases } \\
\hline & & $\mathrm{N}$ & Percent & \\
\hline \multirow[t]{13}{*}{ Whitcomb 4 10/13 ${ }^{\mathrm{a}}$} & 1 & 1 & $0.8 \%$ & $0.8 \%$ \\
\hline & 2 & 20 & $15.9 \%$ & $16.0 \%$ \\
\hline & 3 & 13 & $10.3 \%$ & $10.4 \%$ \\
\hline & 4 & 9 & $7.1 \%$ & $7.2 \%$ \\
\hline & 5 & 19 & $15.1 \%$ & $15.2 \%$ \\
\hline & 6 & 3 & $2.4 \%$ & $2.4 \%$ \\
\hline & 8 & 8 & $6.3 \%$ & $6.4 \%$ \\
\hline & 9 & 3 & $2.4 \%$ & $2.4 \%$ \\
\hline & 10 & 13 & $10.3 \%$ & $10.4 \%$ \\
\hline & 11 & 3 & $2.4 \%$ & $2.4 \%$ \\
\hline & 12 & 13 & $10.3 \%$ & $10.4 \%$ \\
\hline & 13 & 10 & $7.9 \%$ & $8.0 \%$ \\
\hline & 14 & 11 & $8.7 \%$ & $8.8 \%$ \\
\hline Total & & 126 & $100.0 \%$ & $100.8 \%$ \\
\hline
\end{tabular}

a. Group 


\begin{tabular}{|c|c|c|c|c|}
\hline \multicolumn{5}{|c|}{ \$WH51013mr Frequencies } \\
\hline & & \multicolumn{2}{|c|}{ Responses } & \multirow[b]{2}{*}{ Percent of Cases } \\
\hline & & $\mathrm{N}$ & Percent & \\
\hline \multirow[t]{13}{*}{ Whitcomb5 10/13 ${ }^{\mathrm{a}}$} & 1 & 1 & $1.6 \%$ & $1.7 \%$ \\
\hline & 2 & 8 & $13.1 \%$ & $13.3 \%$ \\
\hline & 3 & 4 & $6.6 \%$ & $6.7 \%$ \\
\hline & 4 & 7 & $11.5 \%$ & $11.7 \%$ \\
\hline & 5 & 13 & $21.3 \%$ & $21.7 \%$ \\
\hline & 6 & 2 & $3.3 \%$ & $3.3 \%$ \\
\hline & 8 & 5 & $8.2 \%$ & $8.3 \%$ \\
\hline & 9 & 2 & $3.3 \%$ & $3.3 \%$ \\
\hline & 10 & 8 & $13.1 \%$ & $13.3 \%$ \\
\hline & 11 & 2 & $3.3 \%$ & $3.3 \%$ \\
\hline & 12 & 3 & $4.9 \%$ & $5.0 \%$ \\
\hline & 13 & 4 & $6.6 \%$ & $6.7 \%$ \\
\hline & 14 & 2 & $3.3 \%$ & $3.3 \%$ \\
\hline Total & & 61 & $100.0 \%$ & $101.7 \%$ \\
\hline
\end{tabular}

a. Group

\$C021020mr Frequencies

\begin{tabular}{|c|c|c|c|c|}
\hline \multicolumn{5}{|c|}{ \$C021020mr Frequencies } \\
\hline & & \multicolumn{2}{|c|}{ Responses } & \multirow[b]{2}{*}{ Percent of Cases } \\
\hline & & $\mathrm{N}$ & Percent & \\
\hline \multirow[t]{12}{*}{ Charter Oak 2 10/20a } & 1 & 1 & $0.8 \%$ & $0.9 \%$ \\
\hline & 2 & 19 & $15.4 \%$ & $16.2 \%$ \\
\hline & 3 & 12 & $9.8 \%$ & $10.3 \%$ \\
\hline & 4 & 16 & $13.0 \%$ & $13.7 \%$ \\
\hline & 5 & 17 & $13.8 \%$ & $14.5 \%$ \\
\hline & 7 & 1 & $0.8 \%$ & $0.9 \%$ \\
\hline & 8 & 6 & $4.9 \%$ & $5.1 \%$ \\
\hline & 9 & 6 & $4.9 \%$ & $5.1 \%$ \\
\hline & 10 & 19 & $15.4 \%$ & $16.2 \%$ \\
\hline & 11 & 13 & $10.6 \%$ & $11.1 \%$ \\
\hline & 13 & 10 & $8.1 \%$ & $8.5 \%$ \\
\hline & 14 & 3 & $2.4 \%$ & $2.6 \%$ \\
\hline Total & & 123 & $100.0 \%$ & $105.1 \%$ \\
\hline
\end{tabular}

a. Group

\section{\$CO41020mr Frequencies}

\begin{tabular}{|c|c|c|c|c|}
\hline \multicolumn{5}{|c|}{ \$CO41020mr Frequencies } \\
\hline & & \multicolumn{2}{|c|}{ Responses } & \multirow[b]{2}{*}{ Percent of Cases } \\
\hline & & $\mathrm{N}$ & Percent & \\
\hline \multirow[t]{10}{*}{ Charter Oak 4 10/20 } & 1 & 2 & $6.1 \%$ & $6.1 \%$ \\
\hline & 2 & 7 & $21.2 \%$ & $21.2 \%$ \\
\hline & 3 & 5 & $15.2 \%$ & $15.2 \%$ \\
\hline & 4 & 1 & $3.0 \%$ & $3.0 \%$ \\
\hline & 5 & 7 & $21.2 \%$ & $21.2 \%$ \\
\hline & 8 & 6 & $18.2 \%$ & $18.2 \%$ \\
\hline & 10 & 1 & $3.0 \%$ & $3.0 \%$ \\
\hline & 11 & 1 & $3.0 \%$ & $3.0 \%$ \\
\hline & 13 & 2 & $6.1 \%$ & $6.1 \%$ \\
\hline & 14 & 1 & $3.0 \%$ & $3.0 \%$ \\
\hline Total & & 33 & $100.0 \%$ & $100.0 \%$ \\
\hline
\end{tabular}

a. Group 


\begin{tabular}{|c|c|c|c|c|}
\hline \multicolumn{5}{|c|}{ \$CD11020mr Frequencies } \\
\hline & & \multicolumn{2}{|c|}{ Responses } & \multirow[b]{2}{*}{ Percent of Cases } \\
\hline & & $\mathrm{N}$ & Percent & \\
\hline \multirow[t]{12}{*}{ Community Day $110 / 20^{a}$} & 1 & 1 & $0.9 \%$ & $0.9 \%$ \\
\hline & 2 & 20 & $18.0 \%$ & $18.0 \%$ \\
\hline & 3 & 14 & $12.6 \%$ & $12.6 \%$ \\
\hline & 4 & 11 & $9.9 \%$ & $9.9 \%$ \\
\hline & 5 & 20 & $18.0 \%$ & $18.0 \%$ \\
\hline & 6 & 1 & $0.9 \%$ & $0.9 \%$ \\
\hline & 8 & 7 & $6.3 \%$ & $6.3 \%$ \\
\hline & 9 & 3 & $2.7 \%$ & $2.7 \%$ \\
\hline & 10 & 15 & $13.5 \%$ & $13.5 \%$ \\
\hline & 11 & 9 & $8.1 \%$ & $8.1 \%$ \\
\hline & 13 & 7 & $6.3 \%$ & $6.3 \%$ \\
\hline & 14 & 3 & $2.7 \%$ & $2.7 \%$ \\
\hline Total & & 111 & $100.0 \%$ & $100.0 \%$ \\
\hline \multicolumn{5}{|l|}{ a. Group } \\
\hline \multicolumn{5}{|c|}{ \$CD11013mr Frequencies } \\
\hline \multicolumn{5}{|c|}{ Responses } \\
\hline & & $\mathrm{N}$ & Percent & Percent of Cases \\
\hline \multirow[t]{13}{*}{ Community Day 1 10/13 } & 1 & 2 & $2.1 \%$ & $2.1 \%$ \\
\hline & 2 & 22 & $23.2 \%$ & $23.2 \%$ \\
\hline & 3 & 9 & $9.5 \%$ & $9.5 \%$ \\
\hline & 4 & 14 & $14.7 \%$ & $14.7 \%$ \\
\hline & 5 & 18 & $18.9 \%$ & $18.9 \%$ \\
\hline & 6 & 4 & $4.2 \%$ & $4.2 \%$ \\
\hline & 7 & 2 & $2.1 \%$ & $2.1 \%$ \\
\hline & 8 & 8 & $8.4 \%$ & $8.4 \%$ \\
\hline & 9 & 2 & $2.1 \%$ & $2.1 \%$ \\
\hline & 10 & 8 & $8.4 \%$ & $8.4 \%$ \\
\hline & 11 & 1 & $1.1 \%$ & $1.1 \%$ \\
\hline & 12 & 1 & $1.1 \%$ & $1.1 \%$ \\
\hline & 13 & 4 & $4.2 \%$ & $4.2 \%$ \\
\hline Total & & 95 & $100.0 \%$ & $100.0 \%$ \\
\hline
\end{tabular}

a. Group

\section{Copyrights}

Copyright for this article is retained by the author(s), with first publication rights granted to the journal.

This is an open-access article distributed under the terms and conditions of the Creative Commons Attribution license which permits unrestricted use, distribution, and reproduction in any medium, provided the original work is properly cited. 